\title{
SYNTHESIS OF 9-(4-METHOXYPHENYL)-3,3,6,6-TETRA-3,4,5,6,7,9- HEXAHYDRO-2H-XANTENE-1 USING LIME AND LEMON JUICE AS THE ENVIRONMENTALLY FRIENDLY CATALYST AND ITS ANTIOXIDANT ACTIVITY
}

\author{
Rini Retnosari ${ }^{1}$, Nurul Ultiyati ${ }^{1}$, Siti Marfu'ah ${ }^{1}$, Aman Santoso ${ }^{1}$, \\ Ihsan Budi Rachman ${ }^{1,2}$ \\ ${ }^{1}$ Department of Chemistry, Faculty of Mathematics and Natural Sciences, \\ Universitas Negeri Malang, Indonesia \\ Jl. Cakrawala No.5, Sumbersari, Kec. Lowokwaru, Kota Malang, Jawa Timur \\ ${ }^{2}$ Regional Environment System Department, Graduate School of Engineering and Science, Shibaura \\ Institute of Technology, 307 Fukasaku, Minuma-ku Saitama 337-8570, Japan \\ E-mail: rini.retnosari.fmipa@um.ac.id
}

Received : 25 Mei 2021 ; revised : 26 Mei 2021 ; accepted : 17 Juni 2021

\begin{abstract}
SYNTHESIS OF 9-(4-METHOXYPHENYL)-3,3,6,6-TETRA-3,4,5,6,7,9- HEXAHYDRO-2H-XANTENE-1 USING LIME AND LEMON JUICE AS THE ENVIRONMENTALLY FRIENDLY CATALYST AND ITS ANTIOXIDANT ACTIVITY. The 9-(4-Methoxyphenyl)-3,3,6,6-tetra-3,4,5,6,7,9-hexahydro-2H-xantene-1 compound, which is addressed as compound 1 in this study, is the derivatives of 1,8-dioxo- octahydroxantene. This compound has a carbonyl group and double bond on beta carbon toward the carbonyl group and benzene ring. The presence of this chromophore helps the compound creates intermediate stabilized by resonance from its interaction with free radicals and has the potential to be an antioxidant. Compound 1 was synthesized from $p$ - methoxybenzaldehyde and dimedone through Knoevenagel condensation reaction using an acid as catalyst. The lime and lemon juice was selected as a catalyst to support green chemistry principle. The obtained product includes white powder with a melting point of $222-224^{\circ} \mathrm{C}$. The IR analysis results, GC-MS, and ${ }^{1} \mathrm{H}-\mathrm{NMR}$ data show that the compound structure of Compound 1. Meanwhile, the antioxidant activity test using the DPPH method reveal that Compound 1 has the antioxidant activity with $\mathrm{IC}_{50}$ of 22.74 ppm.
\end{abstract}

Keywords: 1,8-dioxo-octahydroxanthene, green catalyst, lime, lemon, antioxidant

\begin{abstract}
ABSTRAK
SINTESIS SENYAWA 9-(4-METHOXYPHENYL)-3,3,6,6-TETRA-3,4,5,6,7,9- HEXAHYDRO-2H-XANTENE-1 MENGGUNAKAN AIR PERASAN JERUK NIPIS DAN LEMON SEBAGAI KATALIS YANG RAMAH LINGKUNGAN SERTA AKTIVITAS ANTIOKISDANNYA. Senyawa 9-(4-Metoksifenil)-3,3,6,6-tetra-3,4,5,6,7,9heksahidro-2H-xanten-1 yang selanjutnya disebut sebagai senyawa 1 pada penelitian ini merupakan turunan 1,8-dioksooktahidroxantene. Senyawa ini mengandung gugus karbonil dan ikatan ganda pada posisi karbon beta terhadap gugus karbonil serta cincin benzena. Adanya kromofor tersebut menyebabkan senyawa ini mampu menghasilkan intermediet yang terstabilkan oleh resonansi saat berinteraksi dengan radikal bebas dan berpotensi sebagai antioksidan. Senyawa 1 dapat disintesis dari $p$-metoksibenzaldehida dan dimedon melalui reaksi kondensasi Knoevenagel berbantuan asam sebagai katalis. Air perasan jeruk nipis dan lemon dipilih sebagai katalis dalam penelitian ini untuk mendukung prinsip green chemistry. Hasil sintesis yang diperoleh berupa serbuk putih dengan titik lebur sebesar $222-224{ }^{\circ} \mathrm{C}$. Hasil analisis IR, GC-MS, dan ${ }^{1} \mathrm{H}-\mathrm{NMR}$ menunjukkan bahwa struktur senyawa hasil sintesis merupakan senyawa 1. Hasil uji aktivitas antioksidan menggunakan metode DPPH menunjukkan senyawa 1 memiliki aktivitas antioksidan dengan $\mathrm{IC}_{50}$ sebesar 22,74 ppm.
\end{abstract}

Kata kunci: 1,8-diokso-oktahidroxantene, katalis hijau, jeruk nipis, lemon, antioksidan

\section{INTRODUCTION}

One of the compounds reported to have antioxidant activity is 1,8-dioxo-octahydroxantene
(Khatab et al. 2018). Its structural framework is presented in Figure 1. The derivatives compound 
of 1,8-dioxo-octahydroxantene, which has two methoxy groups bound in the benzene ring at the ortho-meta position toward the pyran ring, has the antioxidant activity with each $\mathrm{EC}_{50}$ value of 0.095 $\mathrm{mM}$. Meanwhile, the derivatives compound of 1,8- dioxo-octahydroxantene with two methoxy groups bound in ortho position and one methoxy group bound at the para position toward pyran ring also shows antioxidant activity with $\mathrm{EC}_{50}$ of $0.04 \mathrm{mM}$ (Zukić et al. 2018). It indicates thepresence of

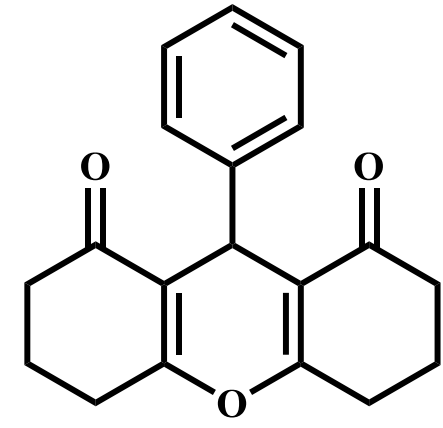

(a)

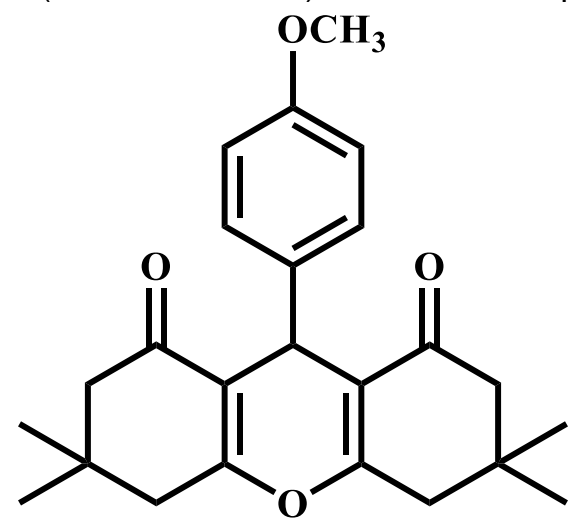

(b)

Figure 1. (a) The framework of the 1,8-dioxo-octahydroxantene compound; and (b) structure of Compound 1

methoxy groups in the benzene toward its antioxidant activity. The activity of 1,8-dioxooctahydroxantene derivative compounds with only one methoxy group at the para position toward the pyran ring (Compound 1) has never been reported, so that this research investigates its antioxidant activity.

Compound 1 can be synthesized from $p$ anisaldehyde and dimedone through Knoevenagel condensation reaction. The acid catalyzes this reaction to protonate the carbonyl groups on $p$-anisaldehyde so that the nucleophile easily attacks it. In addition to antioxidant activity, the derivatives compound of 1,8-dioxooctahydroxantene also possesses other activities, such as anticancer (Mulakayala et al. 2012), anti-microbial (Kusampally et al. 2019), anti-inflammation, and anti-tuberculosis (Napoleon and Nawaz Khan 2014). Consequently, the researchers in the chemical field get attracted to discover the perfect catalyst for its synthesis.

Various catalysts, both homogenous and heterogeneous catalysts, have been reported to stimulate the formation of a 1.8-dioxooctahydroxantene compound, such as $\mathrm{CaCl}_{2}$ (20 mol\%) dispersed in DMSO, $\mathrm{HBr}$ solution (10 mol\%) (Ilangovan et al. 2011), imidazole-1-ilacetic acid (Nazari et al. 2014), ascorbic acid (Napoleon and Nawaz Khan 2014), aluminasulfuric acid (Pramanik and Bhar 2012), antimony trichlorid/ $\mathrm{SiO}_{2}$ (Zhang and Liu 2008), $\mathrm{SiO}_{2}-\mathrm{R}-$ $\mathrm{SO}_{3} \mathrm{H}$ (Mahdavinia, Bigdeli, and Hayeniaz 2009), $\mathrm{ZrOCl}_{2} .8 \mathrm{H}_{2} \mathrm{O}$ (Mosaddegh, Islami, and Hassankhani 2012), ionic solution ([Cmmim][BF $\left.\mathrm{BF}_{4}\right]$ (Dadhania, Patel, and Raval 2017), $\left[\mathrm{Et}_{3} \mathrm{NH}\right]\left[\mathrm{HSO}_{4}\right]$ (Zhou and Deng 2013), [Hmim]TFA (Dabiri, Baghbanzadeh, and Arzroomchilar 2008), and $\mathrm{ZnAl}_{2} \mathrm{O}_{4}$ nanoparticle (Mandlimath,
Sathiyanarayanan 2014). However, those invented catalysts still have weaknesses, such as low yield, long synthesis period, excessive catalyst usage, complicated process, expensive, and not environmentally friendly. Thus, lime and lemon juice was selected as a catalyst on the synthesis of Compound 1. The lime and lemon catalysts have various components, such as citric acid, with the highest composition of $7-8 \%$ (Navarro, Sierra, and Puentes 2013). These catalysts' superiority is a low cost, widely accessible, stable, non-toxic, not quickly evaporated, and environmentally friendly.

\section{MATERIAL AND METHODS}

\section{Materials and Equipments}

The chemical materials used in this research included dimedone and $p$-anisaldehyde (Sigma-Aldrich), ethanol p.a, methanol p.a, chloroform p.a, n-hexane, ethyl acetate, DPPH, aquades, aluminum foil, filter paper, lemon juice, lime juice, and aluminum plate coated by silica gel 60 GF254 with $0.25 \mathrm{~mm}$ thickness (thin layer chromatography).

During this research, the equipment used was a set of glasses, including a beaker, measuring cup, watch glass, erlenmeyer $\mathrm{mL}$, and a set of reflux apparatus, involving two neck round bottom flask. Other than that equipment, the research was also used condenser, test tube, dropper pipette, stirring rod, petri dish, glass preparation, magnetic stirrer, spatula, stirrer hotplate, hose, filler, analytical balance Durascale with an accuracy of $0.001 \mathrm{~g}$, Spectronic 20, infrared spectrophotometer (Central Laboratory of Universitas Negeri Malang), GC-MS Agilent 19091S-433 (Forensic Laboratory of Jakarta), and Spectrometer NMR Agilent DD2 $500 \mathrm{MHz}$ (Bandung Institute of Technology). 


\section{The Preparation of Lime and Lemon Juice}

The limes were obtained from a plantation in Dau, Malang, Indonesia, while the lemons were bought in the Giant Supermarket, Dinoyo, Malang, Indonesia. They were cut into pieces and squeezed. Each of the juices was centrifuged for 15 minutes, and the filtrate was set aside with the decantation method. The attained filtrate was used as the catalyst in this study.<smiles>[R]CC(C)C(C)C(C)C(C)C(C)C</smiles>

Figure 2. Scheme of reaction between $p$-anisaldehyde and dimedone

\section{The Synthesis of Compound 1}

A $0.280 \mathrm{gram}(2 \mathrm{mmol})$ of dimedone was placed in a two-necked flask, then four drops (2 $\mathrm{mmol}$ ) of $p$-anisaldehyde and $10 \mathrm{ml}$ filtrate of lime juice (as the catalyst) were added. After that, it refluxed for four hours at $78^{\circ} \mathrm{C}$ temperature. The reaction results were filtered to separate the residue from the filtrate. The attained residue was dried and recrystallized until the pure compound was obtained, then the same procedure was carried out with the lemon juice catalyst. Its reaction scheme is presented in Figure 2.

\section{The Characterization of Reaction Products}

All of the reaction results were characterized. The characterizations included their melting point using Fisher Scientific 2555 Kerper Boulevard Dubuque (Serial No: 1695080502282), compounds' functional group identification using an infrared spectrophotometer (Shimadzu, IR Prestige 21), along with structure analysis using GC-MS and H-NMR spectrometer. The pure compound was mixed with dry potassium bromide $(\mathrm{KBr})$, then pressed to form $\mathrm{KBr}$ film and it was analyzed using IR spectrophotometer. The analysis of reaction product was done utilizing Agilent 19091S-433 GC-MS, with capillary column (HP-5MS 5\% phenyl methyl siloxane, $30 \mathrm{~m}, 0.25 \mathrm{~mm}$ i.d., 0.25 $\mu \mathrm{m}$ film thickness, $1 \mathrm{~mL} / \mathrm{min}$ initial flow). Helium was used as the carrier gas. The initial temperature was $80^{\circ} \mathrm{C}$ and the final temperature was $300^{\circ} \mathrm{C}$.

\section{The Antioxidant Activity Test of Compound 1}

A 0.001 gram of Compound 1 was dissolved into the chloroform solvent, and a stock of solutions with a different variation of 2, 4, 6, 8, and $10 \mathrm{ppm}$ were prepared. A $2 \mathrm{~mL}$ of each sample with various concentration variation was taken and added with $1 \mathrm{~mL}$ DPPH reagent. The negative control used in this test was sample solvent (chloroform). Each test solution was placed in a dark room at room temperature for 30 minutes. After 30 minutes, their absorbance was measured at $517 \mathrm{~nm}$ wavenumber using Spectronic 20 (Ammelia et al. 2019) ; (Iniyavan, Sarveswari, and Vijayakumar 2015). The inhibition percentage was estimated using the Formula 1.

\%Inhibition $=$ $\frac{\text { Negative control absorbance-Sample absorbance }}{\text { Negative control absorbance }} \times 100 \%$

of the relation between samples' concentration and inhibition percentage was created. The $\mathrm{IC}_{50}$ value was calculated using the linear regression equation from that graph interpolation results. The $\mathrm{IC}_{50}$ is the number that represents the sample concentration thatAfterthat, a chart of the relation between samples' concentration and inhibition percentage was created. The $\mathrm{IC}_{50}$ value was calculated using the linear regression equation from that graph interpolation results. The $\mathrm{IC}_{50}$ is the number that represents the sample concentration that inhibits the DPPH activity by $50 \%$. The lower $\mathrm{IC}_{50}$ value indicates a higher antioxidant activity.

\section{RESULT AND DISCUSSION}

The reaction results between $p$ anisaldehyde and dimedone with lime and lemon juice, as the catalyst, is in the form of white powder. The powder was analyzed using GC-MS. The GC chromatogram from the reaction between $p$-anisaldehyde and dimedone with lime juice catalyst results in four peaks that signifies the formation of four compounds as shown in Figure 3. The first peak with a retention time of 3.968 minutes with an area percentage of $3.54 \%$ is 
presumed to be the remains of the dimedone compound, which is not reacted. It is supported by its spectrum mass data that shows the presence of peak with $\mathrm{m} / \mathrm{z}$ value 140.0 , that is the molecule ion of dimedone. The second peak with 11.157 minutes retention time and $17.93 \%$ area is presumed to be the Knoevenagel condensation results, followed by double bond's dehydration and reduction, as presented in Figure 4. This is proven by the peak with $\mathrm{m} / \mathrm{z}$ value 260.1 , as the ion-molecule of that compound. Meanwhile, the third peak with 11.978 minutes retention time and $50.54 \%$ area is assumed to be the result of Knoevenagel condensation, followed by dehydration that has $258.1 \mathrm{~m} / \mathrm{z}$ value. The fourth peak with 15.372 retention time and $28 \%$ area is presumed to be compound 1, with $380.2 \mathrm{~m} / \mathrm{z}$ value.

In addition, the GC chromatogram of products from $p$-anisaldehyde and dimedone reaction with lemon juice catalyst also result in four peaks. The first peak is assumed to be the dimedone compound that is not reacted. It has 3.933 minutes of retention time and $7.12 \%$. The second peak with 11.114 minutes retention time and $4.64 \%$ area is assumed to be the Knoevenagel condensation results, followed by double bound's dehydration and reduction. The third peak is presumed to be the Knoevenagel condensation results, followed by dehydration since it has 12.020 retention time and $63.88 \%$ area. The last peak with 15.397 minutes retention time and $23.34 \%$ is presumed to be Compound 1 . The GC-MS analysis indicates that both lemon and lime juice can catalyze the reaction between $p$-anisaldehyde and dimedone. However, those catalysts can only catalyze the reaction to the formation of a Knoevenagel condensation product, followed by dehydration. The GC-MS chromatogram area percentage shows that these two catalysts remain hardly facilitate the formation of compound 1. Thus, these catalysts are less effective in catalyzing compound 1, in which the Knoevenagel condensation will be attacked again by dimedone through Michael reaction and cyclization, so that compound $\mathbf{1}$ is formed.

In addition, the lime juice is more effective than lemon in catalyzing the $p$ anisaldehyde and dimedone reaction. It is supported by the higher reaction product and fewer dimedone residue from the lime catalyst than reaction product and remained reactant from the lemon catalyst. The generated compound 1's area percentage from the lime catalyst is also more significant than the lemon catalyst.

\section{$\mathrm{T}$}

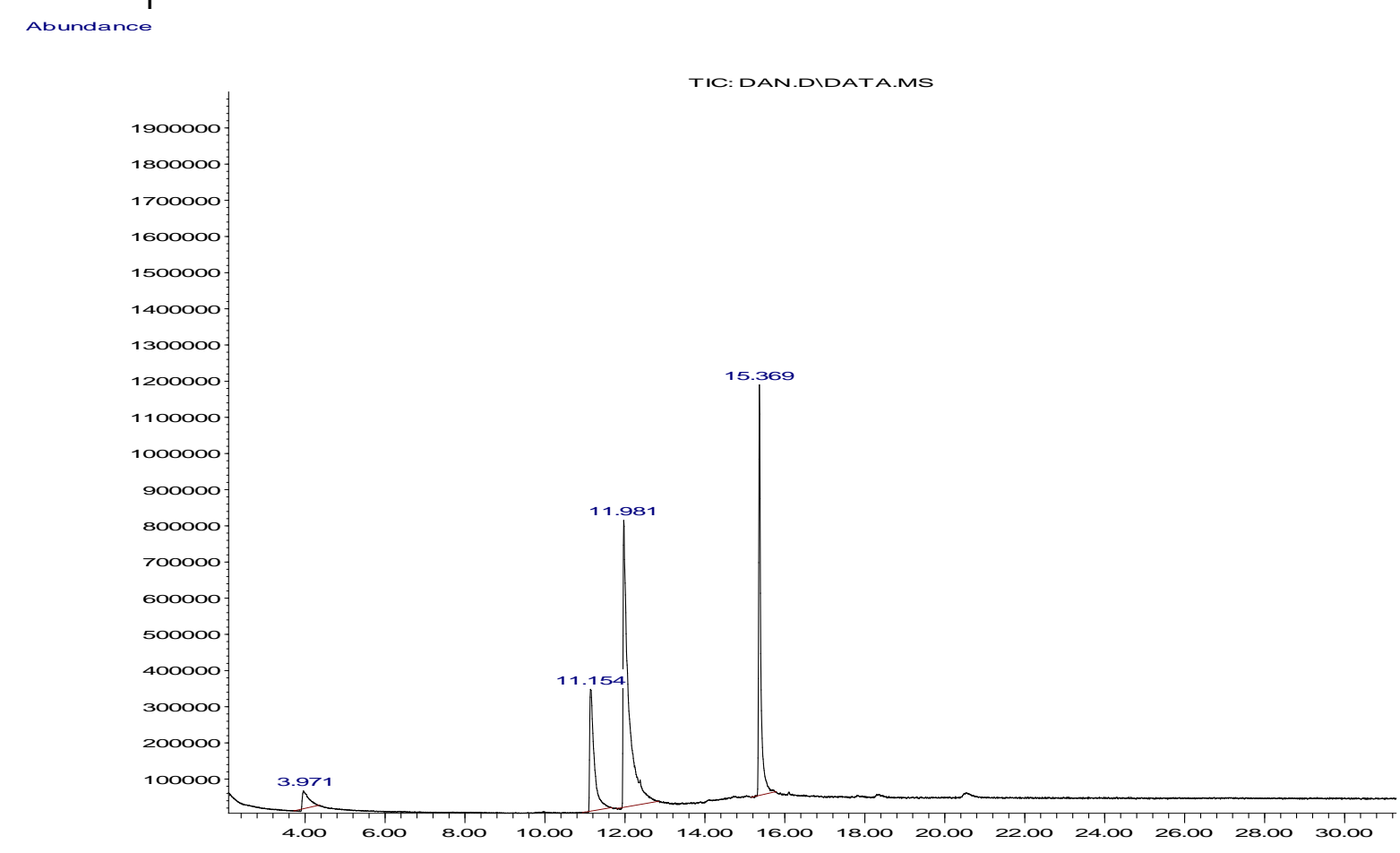

Figure 3. The GC cromatogram of reaction product 


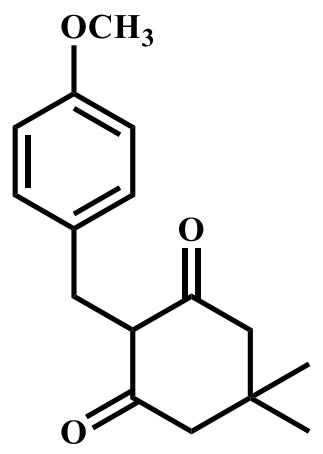

$\mathrm{m} / \mathrm{z}: 260.14$

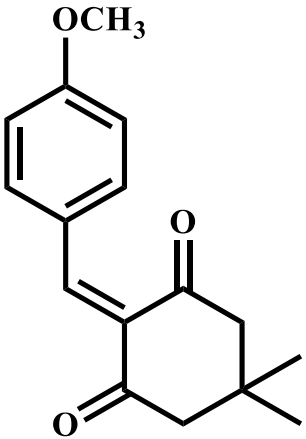

$\mathrm{m} / \mathrm{z}: 258.13$<smiles>COc1ccc(C2C3=C(CC(C)(C)CC3=O)OC3=C2C(=O)CC(C)(C)C3)cc1</smiles>

$\mathrm{m} / \mathrm{z}: \mathbf{3 8 0 . 2 0}$

(a)

(c)

Figure 4. The structure and the $\mathrm{m} / \mathrm{z}$ value of (a) Knoevenagel condensation results, followed by double bond's dehydration and reduction; (b) Knoevenagel condensation result followed by dehydration; (c) Compound 1

The product formation is presumed to be the Knoevenagel condensation results that are followed by double bond dehydration and reduction. It indicates the presence of a redactor compound within the lime and lemon. However, the reduced product's area percentage from the lemon juice catalyst is lower. Thus, lemon catalyst reducing ability is less than the lime catalyst. Besides, the lemon juice catalyst is more effective in synthesizing the dehydrated Knoevenagel product. However, a further study of lime and lemon content is required especially the type of organic acid and their percentage in both materials.

The GC-MS analysis reveals that compound 1 has been formed from the use of lime and lemon juice catalyst. Thus, the purification of compound $\mathbf{1}$ has been carried outs through recrystallization using ethanol. The purification result is in the form of white powder with a melting point of $222-224^{\circ} \mathrm{C}$. Based on its melting point, the recrystallization result can be categorized as pure compound since it has a melting range between $2^{\circ} \mathrm{C}$. This pure product was analyzed using an infrared spectrophotometer and NMR spectrometer.

According to the IR spectrum of compound $\mathbf{1}$, as shown in Figure 5, there is 6 six absorption tape that matches with the absorption type of compound 1 structure. The first absorption band appears at $3003.17 \mathrm{~cm}^{-1}$ wavenumbers with a sharp and robust intensity, indicating the presence of stretching vibrations of aromatic $\mathrm{C}-\mathrm{H}$ bonds. The second band emerges at 2958.8$2935 \mathrm{~cm}^{-1}$ wavenumber with sharp and substantial intensity, representing the stretching vibration of aliphatic $\mathrm{C}-\mathrm{H}$ bonds. The third band at
$1676 \mathrm{~cm}^{-1}$ wavenumber with strong and sharp demonstrating the presence of the stretching vibration of the $\mathrm{C}=\mathrm{O}$ bond. The fourth absorption band is observed at $16625.99 \mathrm{~cm}^{-1}$ wavenumbers with sharp and robust intensity showing the existence of the stretching vibration of the $\mathrm{C}=\mathrm{C}$ aromatic bond. Meanwhile, the fifth band is at $1606.7 \mathrm{~cm}^{-1}$ wavenumbers with similar sharp and robust intensity, representing the $\mathrm{C}=\mathrm{C}$ aliphatic bond's stretching vibration. The last band is at 1301.95-1033.85 $\mathrm{cm}^{-1}$ wavenumber with the same vigorous and sharp intensity, indicating the C-O carbonyl bond's vibrational stretch.

The H-NMR spectrum of compound $\mathbf{1}$ is illustrated in Figure 6 . The singlet signal at the $4.4397 \mathrm{ppm}(1 \mathrm{H})$ chemical shift is the typical signal of 1,8-dioxo-octahydroxantene derivative compounds. This signal marks the proton of the methine group in the pyran ring with no neighboring protons so that it appears as a singlet. The singlet signals at $0.8862 \mathrm{ppm}(6 \mathrm{H})$ and $1.0171 \mathrm{ppm}(6 \mathrm{H})$ represent the proton in the four methyl groups bound on cyclohexane-2-en1-one. The four singlet signals $(8 \mathrm{H})$ in the chemical shift of 2.041 ppm, 2.0737 ppm, 2.2279 ppm, and 2.2603 ppm illustrate the proton in four methylene group bound on cyclohexane-2-en-1one. Meanwhile, the singlet signal at 3,6632 ppm $(3 \mathrm{H})$ shows the proton in the methoxy group on the benzene ring. Simultaneously, the doublet signal at the chemical shift of $6.75775 \mathrm{ppm}(2 \mathrm{H})$ and $7.04945 \mathrm{ppm}(2 \mathrm{H})$ represent the proton within the aromatic ring. The chemical shift data on ${ }^{1} \mathrm{H}-$ NMR spectrum of Compound 1 was compared with the data of similar compound in recent finding, as presented in Table 1.

Table 1. The chemical shift data of compound 1 in this study and the previous findings

$\begin{array}{ll}\text { Protons } & \text { Chemical shift in this study }\left({ }^{1} \mathrm{H}-\right. \\ \left.\mathrm{NMR}, 500 \mathrm{MHz}, \mathrm{CDCl}_{3}\right)(\mathrm{ppm})\end{array}$
Chemical shift reported by (Kusampally et al. (2019) ( $\left.{ }^{1} \mathrm{H}-\mathrm{NMR}, 400 \mathrm{MHz}, \mathrm{CDCl}_{3}\right)$

(ppm)

\begin{tabular}{lll}
\hline $\mathrm{H}-1 \& \mathrm{H}-2$ & $0.8862(6 \mathrm{H}, s)$ & $1.01(6 \mathrm{H}, \mathrm{s})$ \\
\hline
\end{tabular}




\begin{tabular}{lll}
\hline $\mathrm{H}-3$ \& H-7 & $2.041(2 \mathrm{H}, s)$ & $2.21(4 \mathrm{H}, d d)$ \\
& $2.0737(2 \mathrm{H}, s)$ & \\
\hline $\mathrm{H}-5$ & $4.4397(1 \mathrm{H}, s)$ & $4.71(1 \mathrm{H}, s)$ \\
\hline $\mathrm{H}-4$ \& H-6 & $2.2279(2 \mathrm{H}, s)$ & $2.48(4 \mathrm{H}, s)$ \\
\hline $\mathrm{H}-8$ \& H-9 & $2.2603(2 \mathrm{H}, s)$ & $1.11(6 \mathrm{H}, s)$ \\
\hline $\mathrm{H}-10$ \& & $1.0171(6 \mathrm{H}, s)$ & $6.77(2 \mathrm{H}, d)$ \\
$\mathrm{H}-11$ & $6.75775(2 \mathrm{H}, d)$ & $7.22(2 \mathrm{H}, d)$ \\
$\mathrm{H}-12 \&$ & & \\
\hline $\mathrm{H}-13$ & $7.04945(2 \mathrm{H}, d)$ & $3.74(3 \mathrm{H}, s)$ \\
\hline
\end{tabular}

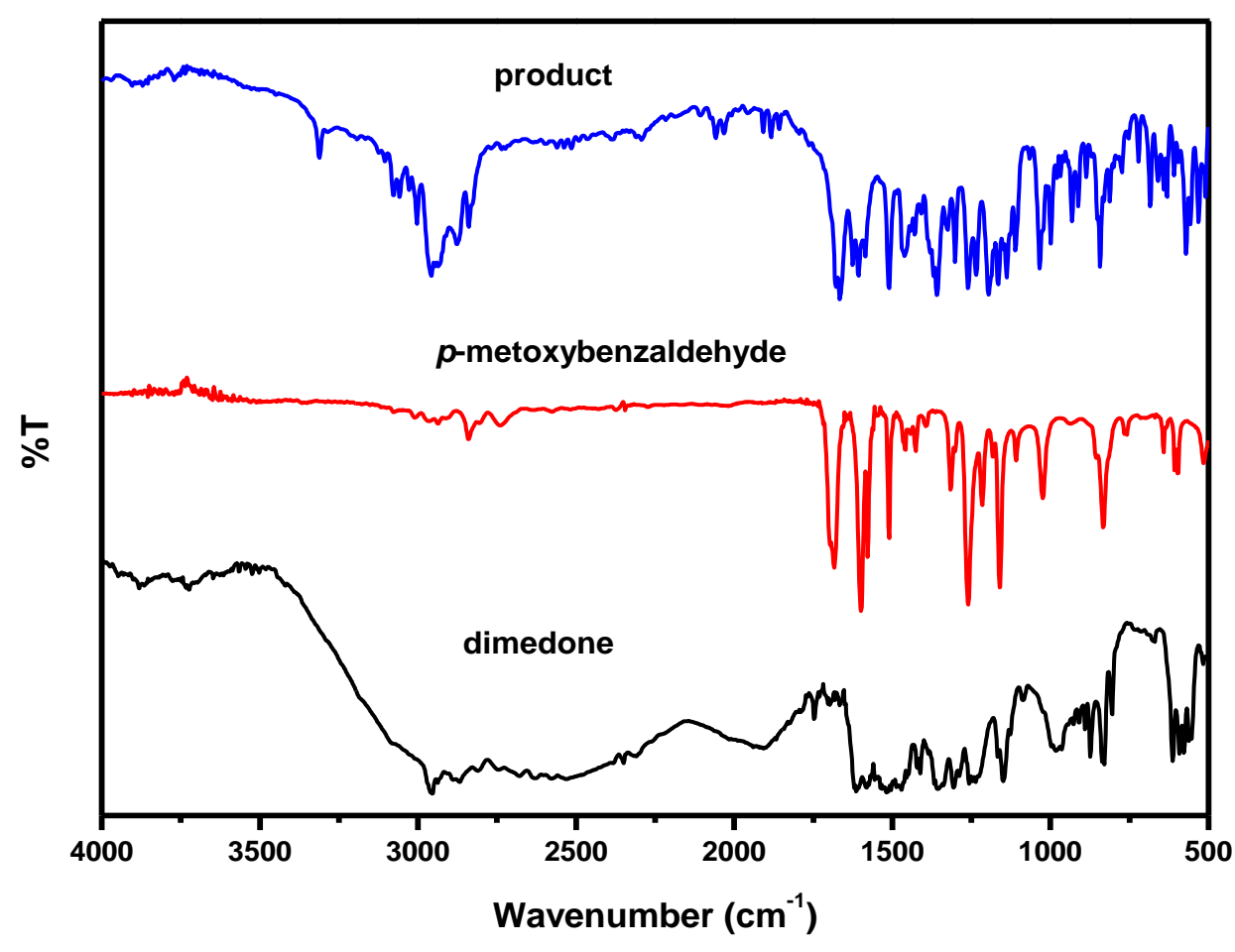

Figure 5. IR spectrum of dimedone, p-metoxybenzaldehyde, and reaction product

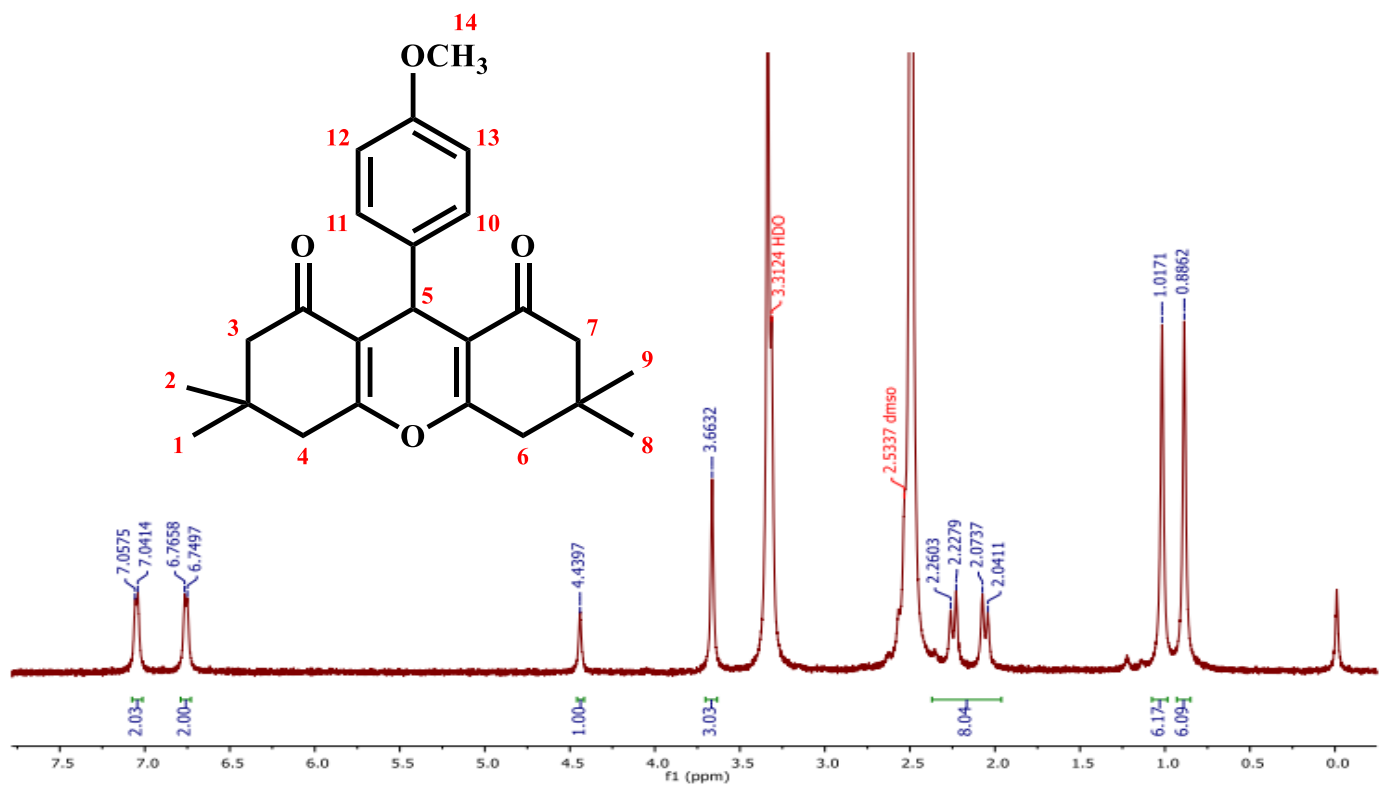

Figure 6. H-NMR spectrum of compound 1 
The antioxidant activity of compound $\mathbf{1}$ was investigated using the DPPH method due to its advantages, such as its simplicity, fast and uncomplicated process, and not requiring many samples (Widyasanti, Rohdiana, and Ekatama 2016). The antioxidant activity test was completed using the DPPH method by the purple color intensity changing on DPPH, which is linear to the DPPH solution concentration reduction. If the DPPH molecule takes the hydrogen atom of the presumed to be antioxidant compound, the color transforms into yellow, or the purple color intensity decreases. This color change is caused by the formation of diphenyl picryl hydrazine compounds (Molyneux 2004). This color intensity transformation can be determined by measuring its absorbance at $517 \mathrm{~nm}$ wavenumber. The absorbance data and inhibition percentage of compound 1 on the antioxidant activity test are shown in Table 2.

Table 2. The Absorbance Value and Inhibition Percentage of Compound 1 Concentration Variation

\begin{tabular}{ccc}
\hline Sample Concentration $(\mathrm{ppm})$ & Absorbance & Inhibition Percentage (\%) \\
\hline 0 & 0.8899 & 0 \\
2 & 0.686 & 22.9127 \\
4 & 0.668 & 24.9354 \\
6 & 0.632 & 28.9807 \\
8 & 0.630 & 29.2055 \\
10 & 0.588 & 33.9252 \\
\hline
\end{tabular}

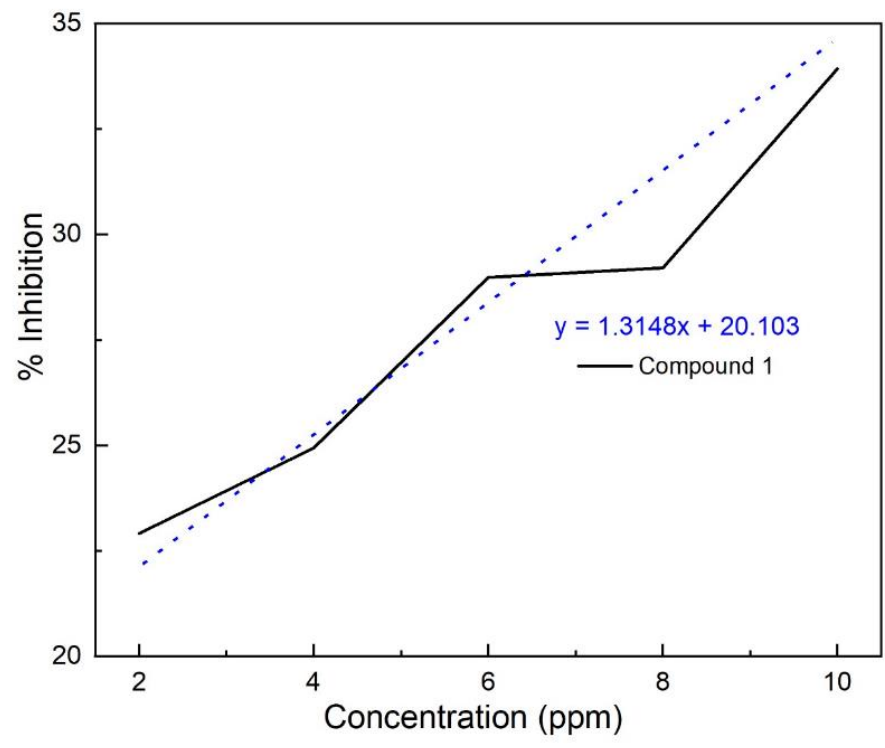

Figure 7. The chart of inhibition percentage toward compound 1 concentration variation

The compound 1 concentration increase accelerates its inhibition percentage. It occurs because the higher concentration carries many more molecules that donate the $\mathrm{H}$ atom on the $\mathrm{DPPH}$, so it completes the lack of electrons. The more stabilized DPPH compound reduces the color intensity; thereby, the attained absorbance value also decreases. The lower absorbance value indicates a higher inhibition percentage. Meanwhile, the excellent inhibition percentage represents the more significant antioxidant potential. The $\mathrm{IC}_{50}$ value was decided by creating an inhibition percentage chart on compound 1 concentration to obtain the linear regression equation graph, as shown in Figure 7. By substituting the $y$ with 50 , then the obtained $\mathrm{IC}_{50}$ value of compound $\mathbf{1}$ is $22.7388 \mathrm{ppm}$. Additionally, other studies have reported that a compound can be categorized as an active antioxidant if it has an IC50 $<100 \mathrm{ppm}$. Therefore, compound $\mathbf{1}$ is classified as an active antioxidant compound. The $\mathrm{IC}_{50}$ value is a number that represents the tested samples' concentration (ppm) and its ability to inhibit the $50 \%$ oxidation process; thus, a smaller $\mathrm{IC}_{50}$ value indicates its high antioxidant activity (Zuhra, Tarigan, and Sihotang 2008).

\section{CONCLUSION}

Compound 1 has been successfully synthesized using $\mathrm{p}$-anisaldehyde and dimedone using lime and lemon juice, but the reaction yield remains low. The lime and lemon juices are more useful for the catalyst of Knoevenagel condensation product formation, which is followed by dehydration on the synthesis of 1.8dioxo-octahydroxantene derivative, particularly the Compound 1 . The reaction situation's optimization should be improved to increase the 
compound 1 reaction yield, such as the amount of catalyst, temperature, and reactant mole ratio. The superiority of lime and lemon juice as a catalyst are economical and non-toxic. Compared to the other catalysts, this reported catalyst

\section{ACKNOWLEDGEMENT}

The authors would like to acknowledge the funding from PNBP Universitas Negeri Malang 2019 for financial support of this research.

\section{REFERENCES}

Ammelia, S.M., Retnosari, R., Utomo, Y., Sukarianingsih, D., Wonorahardjo, S. 2020. "The changing profiles of organosulfuric compounds during black garlic processing", IOP Conference Series: Earth and Environmental Science, 475, 1, $1-8 "$

Dabiri, M., Baghbanzadeh, M. dan Arzroomchilar, E. 2008. Methylimidazolium triflouroacetate ([Hmim]TFA): An efficient reusable acidic ionic liquid for the synthesis of 1,8-dioxooctahydroxanthenes and 1,8-dioxodecahydroacridines." Catalysis Communications, 9 (5): 939-42, https://doi.org/10.1016/j.catcom.2007.09.0 23.

Dadhania, A. N., Patel, V.K., dan Raval. D. K. 2017. "Ionic Liquid Promoted Facile and Green Synthesis of 1,8-DioxoOctahydroxanthene Derivatives under Microwave Irradiation." Journal of Saudi Chemical Society, 21 : S163-69. https://doi.org/10.1016/j.jscs.2013.12.003.

llangovan, A., Subramani, M., Samraj, M., dan Sundaram, M. 2011. "A Highly Efficient Green Synthesis of 1, 8-DioxoOctahydroxanthenes." Chemistry Central Journal, $\quad 5 \quad(1)$ : 81. https://doi.org/10.1186/1752-153X-5-81.

Iniyavan, P., Sarveswari, S., dan Vijayakumar, V. 2015. "Synthesis and antioxidant studies of novel bi-, tri-, and tetrapodal 9-aryl-1,8dioxo-octahydroxanthenes." Tetrahedron Letters, $56 \quad$ (11): 1401-6. https://doi.org/10.1016/j.tetlet.2015.01.162

Khatab, T. K, El- Mekabatyl, A., Gamala, Z. M., dan Kandil, E. M. 2018. "An efficient catalytic synthesis of 1,8-dioxooctahydroxanthene derivatives with antioxidant scanning." Egypt. J. Chem, 61, 4, 661-666.

Kusampally, U., Varala, R., Kamatala, C. R., dan Abbagoni, S. 2019. "Rate accelerations with zeolite $Y$ in the synthesis possesses a more excellent performance. Compound 1 has a robust antioxidant activity with $\mathrm{IC}_{50}$ of $22.7388 \mathrm{ppm}$ to be used as a new antioxidant source. The future study should examine the toxicity of compound 1 .

of octahydroxanthenes and benzoxanthenes and their simple bio assay data." Chem. Data Collect, 20, 1-9.

Mahdavinia, G. H., Bigdeli, M. A., dan Hayeniaz, Y. S. 2009. "Covalently anchored sulfonic acid on silica gel $\left(\mathrm{SiO}_{2}-\right.$ $\mathrm{R}-\mathrm{SO}_{3} \mathrm{H}$ ) as an efficient and reusable heterogeneous catalyst for the one-pot synthesis of 1,8-dioxo-octahydroxanthenes under solvent-free conditions." Chinese Chemical Letters ,20 (5): 539-41. https://doi.org/10.1016/j.cclet.2008.12.026.

Mandlimath, T. R., Umamahesh, B., dan Sathiyanarayanan, K. I. 2014. "Rapid one pot synthesis of xanthene derivatives by an efficient and reusable nano- $\mathrm{ZnAl}_{2} \mathrm{O}_{4}-\mathrm{An}$ insight into a new process." Journal of Molecular Catalysis A: Chemical, 391: 198-207.

https://doi.org/10.1016/j.molcata.2014.04. 030.

Molyneux, P. 2004. "The Use of the Stable Free Radical Diphenylpicryl- Hydrazyl (DPPH) for Estimating Antioxidant Activity". J. Sci. Technol, 26 (2): 9.

Mosaddegh, E., Islami, M. R., dan Hassankhani, A. 2012. " $\mathrm{ZrOCl}_{2} \cdot 8 \mathrm{H}_{2} \mathrm{O}$ as an Efficient and Recyclable Catalyst for the Clean Synthesis of Xanthenedione Derivatives under Solvent-Free Conditions." Arabian Journal of Chemistry, 5 (1): 77-80. https://doi.org/10.1016/j.arabjc.2010.07.02 7.

Mulakayala, N., Murthy, P.V.N.S., Rambabu, D., Aeluri, M., Adepu, R., Krishna, G.R., dan Reddy, C. M.. 2012. "Catalysis by Molecular lodine: A Rapid Synthesis of 1,8Dioxo-Octahydroxanthenes and Their Evaluation as Potential Anticancer Agents." Bioorganic \& Medicinal Chemistry Letters, 22 (6): 2186-91. https://doi.org/10.1016/j.bmcl.2012.01.126

Napoleon, A. A., dan Nawaz Khan,F.-R. 2014. "Potential Anti-Tubercular and in Vitro AntiInflammatory Agents: 9-Substituted 1,8Dioxo-Octahydroxanthenes through Cascade/Domino Reaction by Citric Fruit Juices." Medicinal Chemistry Research, 23 (11): 4749-60. https://doi.org/10.1007/s00044-014-1033$\mathrm{x}$.

Navarro, D. C. A., Sierra, C. A., dan OchoaPuentes, C. 2013. "Aqueous citric acid as 
'green' reaction media for the synthesis of octahydroxanthenes." Rev. Colomb. Quim., 42, 168-186.

Nazari, S., Keshavarz, M., Karami, B., Iravani, N., dan Vafaei-Nezhad, M. 2014 "Chemlnform Abstract: Imidazol-1-yl-acetic Acid as a Novel Green Bifunctional Organocatalyst for the Synthesis of 1,8Dioxooctahydroxanthenes under SolventFree Conditions." Chinese Chemical Letters, 25,

2. https://doi.org/10.1002/chin.201428139.

Pramanik, A dan Bhar, S. 2012. "Aluminasulfuric acid catalyzed eco-friendly synthesis of xanthenediones." Catalysis Communications, 20: 17-24. https://doi.org/10.1016/j.catcom.2011.12.0 36.

Widyasanti, A., Rohdiana, D., dan Ekatama, N. 2016. "Aktivitas antioksidan ekstrak teh putih (Camellia sinensis) dengan metode DPPH (2,2-difenil -1- pikrilhidrazil)." Fortech, 1, 1, 1-9.

Zhang, Z-H dan Liu, Y,-H. 2008. "Antimony trichloride $/ \mathrm{SiO}_{2}$ promoted synthesis of 9- ary-3,4,5,6,7,9-hexahydroxanthene-1,8diones." Catalysis Communications, 9 (8): 1715-19.

https://doi.org/10.1016/j.catcom.2008.01.0 31.

Zhou, Z dan Deng, X. 2013. " $\left[\mathrm{Et}_{3} \mathrm{NH}\right]\left[\mathrm{HSO}_{4}\right]$ catalyzed efficient and green synthesis of 1,8-dioxo-octahydroxanthenes." J. Mol. Catal. Chem., 367, 99-102, doi: 10.1016/j.molcata.2012.11.002.

Zuhra, C. F., Tarigan, J. Br., dan Sihotang, H. 2008. "Aktivitas antioksidan senyawa flavonoid dari daun katuk (Sauropus androgunus (L) Merr.)." Jurnal Biologi Sumatera, 3, 1, 7-10.

Zukić, S., Veljović, E., Špirtović-Halilović, S., Muratović, S., Osmanović, A., Trifunović, S., Novaković, I., dan Završnik, D. 2018. "Antioxidant, Antimicrobial and Antiproliferative Activities of Synthesized 2,2,5,5-Tetramethyl-9-Aryl-3,4,5,6,7,9Hexahydro-1H-Xanthene-1,8(2H)-Dione Derivatives." Croatica Chemica Acta, 91 (1). https://doi.org/10.5562/cca3225. 